\title{
Short Communication: Molecular study on mt-DNA COX2 gene of Sumatran elephant (Elephas maximus sumatranus)
}

\author{
DENY SETYO WIBOWO ${ }^{1}$, RINI WIDAYANTI ${ }^{2}$, MACHMUD ASVAN ${ }^{3}$, PRISTA DWI RESTANTI $^{4}$, \\ HERY WIJAYANTO' ${ }^{1, \bullet}$ \\ ${ }^{1}$ Department of Anatomy, Faculty of Veterinary Medicine, Universitas Gadjah Mada. Jl. Fauna No. 2, Karangmalang, Depok, Sleman 55281, \\ Yogyakarta, Indonesia. Tel.: +62-274-6492088, Fax.: +62-274-560861, `email: herykh@ugm.ac.id \\ ${ }^{2}$ Department of Biochemistry, Faculty of Veterinary Medicine, Universitas Gadjah Mada. Jl. Fauna No. 2, Karangmalang, Depok, Sleman 55281, \\ Yogyakarta, Indonesia \\ ${ }^{3}$ Gembira Loka Zoo. J1. Kebun Raya No. 2, Rejowinangun, Yogyakarta City 55171, Yogyakarta, Indonesia \\ ${ }^{4}$ Jawa Timur Conservation Institute. Jl. Kartika No. 2, Kota Wisata, Batu 65314, East Java, Indonesia
}

Manuscript received: 22 September 2020. Revision accepted: 27 January 2021.

\begin{abstract}
Wibowo DS, Widiyanti R, Asvan M, Restanti PD, Wijayanto H. 2021. Short Communication: Molecular study on mt-DNA COX2 gene of Sumatran elephant (Elephas maximus sumatranus). Biodiversitas 22: 1063-1068. Sumatran elephant is the only subspecies of Asian elephants that receives a critically endangered status from the International Union for Conservation and Nature Resources (IUCN). Identifying the genetic marker of Sumatran elephants is, therefore, important for their conservation. This study aimed to identify the Sumatran elephant based on specific mitochondrial DNA markers of the Cytochrome c oxidase subunit II (COX2) gene. It is an exploratory research considering the limited data and research about the genetic, especially the COX2 of Sumatran elephant (Elephas maximus sumatranus). Forward and reverse sequencing of PCR products was conducted using the primary COX2 from Sumatran elephant samples. The results of the subsequent gene sequencing were aligned with the sequences of other Asian elephants from Genbank using Clustal W software and analyzed using the MEGA program version 6.06. The analysis of genetic distance based on COX2 constituent nucleotides calculated with Kimura's two-parameter method showed that the genetic distance between Elephas maximus sumatranus and Elephas maximus outside of Sumatra was $0.25 \%$. The phylogenetic trees analyzed using the maximum-likelihood based on nucleotide sequences showed a high homogeneity. The ratio of Elephas maximus sumatranus with Elephas maximus shows levels of nucleotide mutations which are nine nucleotides and four nucleotides. These results indicated that the COX2 gene could not identify the individual species of Sumatran elephant because of the high intraspecies homogeneity, but it detected the interspecies divergence clustered in Asian elephant clade.
\end{abstract}

Keywords: COX2 gene, Elephas maximus sumatranus, genetic diversity, mitochondrial DNA, Sumatran elephant

Abbreviations: COX2: Cytochrome c oxidase subunit II; IUCN: Internasional Union for Conservation and Nature Resources; HTI: Hutan Tanaman Industri/Industrial Forest Plantations; mt-DNA: Mitochondrial DNA; ND3: NADH dehydrogenase 3; EDTA: Ethylenediaminetetraacetic acid; TBE: Tris/Borate/EDTA; PCR: Polymerase Chain Reaction

\section{INTRODUCTION}

Indonesia is the richest country for mammal species diversity, which amounts to 701 species. One of the largest mammals that have lived in Indonesia since ancient times is the elephants. The habitat of Asian elephants in Indonesia now spreads in two islands, Sumatra and Borneo, but their population continues to decline due to hunting or land clearing (Sulandari and Zein 2012). Sumatran elephants are the only subspecies of Asian elephant on the red list of the International Union for Conservation and Nature Resources (IUCN). The status of Sumatran elephants is very endangered because 70 percent of them live outside the conservation areas, such as HTI areas (Industrial Forest Plantations), forests around oil palm plantations, even coal mining (Ministry of Forestry 2007).

In the second decade of the 21st century, the existence of Asian elephants was increasingly threatened. Out of 13 countries populated by elephants, five (Bangladesh,
Bhutan, China, Nepal, and Vietnam) have under 200 wild elephants on average (Islam et al. 2011; Jigme 2011; Zhang 2011; Pradhan et al. 2011; Ly 2011). Meanwhile, Cambodia and Laos have less than 1,000 wild elephants (Maltby and Bourchier 2011). In Sumatra, Indonesia, elephants have been labeled Critically Endangered (red list) (Fernando and Pastorini 2011).

Azmi and Gunaryadi (2011) stated that the populations of Asian elephants in Sumatra ranged from 2400 to 2800, occupying $456,167 \mathrm{~km}^{2}$ inhabited by $47,728,472$ humans. The elephant population spreads across 44 locations in seven provinces of Sumatra, namely Nangroe Aceh Darussalam, North Sumatra, Riau, Jambi, Bengkulu, South Sumatra, and Lampung (Ministry of Forestry 2007). There are an estimated 2,040 elephants in Kalimantan that mostly inhabit the Central Forest area (Alfred et al. 2010).

Identifying the genetic marker of Sumatran elephants is essential for their conservation. The unavailability of comprehensive morphological data and genetic markers as 
the specific markers is a serious obstacle to conserving the endangered Sumatran elephant. This study aimed to identify Sumatran elephants (Elephas maximus sumatranus) individually based on the specific mitochondrial DNA markers of the Cytochrome C oxidase subunit II (COX2) gene to fill the gap in data and research on the genetic of Sumatran elephant, especially in COX2.

Mitochondrial DNA is relatively small (16.5 kb), allowing an ease of DNA amplification and producing more DNA copies. Some mitochondrial DNA metabolisms are advantageous as the basis for genetic forensics due to their high level of mutation, which is only derived from the female elephants and their smaller DNA strand than the nuclear DNA. In addition, female elephants are not as mobile as the male elephants since they only move around their birthplace (Widayanti et al. 2010). Cytochrome oxidase c complex has a dimeric structure that spans the inner mitochondrial membrane, and most protein is exposed to the inner matrix of the mitochondrion. Therefore, it plays a critical role in producing ATP for energy metabolism and catalyzing the transferred electron (Chicherin et al. 2019).

The mitochondrial genome is capable of evolving 5-10 times as fast as the nuclear DNA. The coding and noncoding mt-DNA areas are historically used for evolution research and genetic relation between species (Widiyanti et al. 2010). In primates, $C O X 2$ and ND3 genes undergo more mutation than the other mt-DNA genes (Galina et al. 2003). The size of the COX2 gene is $684 \mathrm{bp}$, located between the tRNA $^{\text {Asp }}$ gene (on the left side or front) and gen tRNA ${ }^{\text {Lys }}$ gene (on the right side or end) in mt-DNA (Figure 1) (Schmitz et al. 2002).

Sulandari and Zein (2012) studied the mitochondrial DNA of African elephants using D-loop in the MDL3 and MDL5 genes and categorized them into eight groups. This method is considerably helpful to accurately determine (62$84 \%$ ) from which countries the elephant ivory has originated. Mitochondria contain compacted genes simplified by introns removal and little duplication, so the regions between genes are very short. The partial cytochrome $\mathrm{b}$ and hypervariable D-loop region in mt-DNA has been used in species identification for forensic evidence and particularly suitable for the genetic analysis for population and related taxa (Lee et al. 2012).

Based on the specificity of mitochondrial DNA strands of Sumatran elephants to their habitat area, the government can easily trace the origins of traded elephant ivory to implement the legal authority of cracking down the illegal trade. This goal confirms previous research (Ishida et al. 2013).

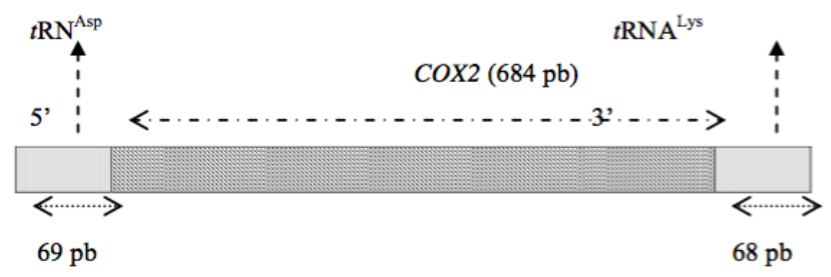

\section{MATERIALS AND METHODS}

\section{Sample}

Blood samples were drawn from five captive Sumatran elephants in Jawa Timur Park Conservation Institute. The elephants were originated from Lampung (two samples) and Palembang (three samples) that represent elephants from the south region of Sumatran island.

This study had received an ethical clearance number 002.0/EC-FKH/Int./2019 issued by the Veterinary Medicine Ethical Clearance Committee, Universitas Gadjah Mada (UGM), Yogyakarta, Indonesia (accepted on March 18, 2019).

\section{Sample collection}

Blood samples of the Sumatran elephants were collected using a $5 \mathrm{ml}$ syringe from the auricular vein in the dorsal part of the elephant's ears. This invasive sample collection was conducted carefully by an expert (veterinarian) to select the right veins side-by-side with the arteries. The ears were cleaned using alcohol to allow vasodilation, followed by damming in the veins' proximal part. The collected blood was inserted into a tube pre-filled with EDTA, stored in an ice-packed coolbox to keep the blood sample from lysis, and refrigerated at $4^{\circ} \mathrm{C}$.

\section{DNA isolation}

DNA isolation was carried out at the UGM Biochemistry Laboratory, Faculty of Veterinary Medicine. Total blood samples collected using a tube containing $10 \%$ EDTA anticoagulant were isolated and purified using a Qiagen DNA isolation kit. The isolation was detected by $1 \%$ agarose gel using a 1xTBE buffer in Submarine Electrophoresis (Hoefer, USA). The gel was then stained with Bioatlas (Genaid) and observed with UV at $260 \mathrm{~nm}$. After the DNA finished, the isolation was refrigerated at$20^{\circ} \mathrm{C}$.

\section{Primer design}

The results of DNA isolation were used as the template for PCR amplification. COX2 gene amplification used forward and reverse primers designed with the primer 3 program (http://www.genome.wi.mit.edu/cgi.bin/primr3.cgi/results_ from-primer3) based on the sequence data of the Elephas maximus mitochondrial genome (Access number EF588275.2). The primary base sequence for the amplification of the Cytochrome $c$ oxidase subunit II (COX2) gene from the Sumatran Elephant sample is shown in Table 1.

Tables 1. Primary base sequence for amplifying the COX2 gene

\begin{tabular}{|c|c|c|c|}
\hline Target $\mathbf{R} / \mathbf{f}$ & Base sequence & $\begin{array}{l}\text { Number } \\
\text { of bases }\end{array}$ & $\begin{array}{l}\text { Tm } \\
\left({ }^{\circ} \mathrm{c}\right)\end{array}$ \\
\hline COX2 F & 5' CTTTATGCCTTCTCCAACAG 3' & 20 & 53.98 \\
\hline 900 bp R & 5' CGTAAGTACAATCACGACTG 3' & 20 & 53.96 \\
\hline
\end{tabular}

Figures 1. The scheme of COX2 gene (Howell 1985 and Schimtz et al. 2002). 


\section{Amplification}

The total DNA extraction results as DNA prints were amplified using a PCR (Infinigen) machine. The amplification of each COX2 gene used a pair of primers (Table 1). Subsequently, the tubes were placed into a thermal cycler and subjected to an initial denaturation at $94^{\circ} \mathrm{C}$ for $2 \mathrm{~min}$, followed by 35 -cycle denaturation at $94^{\circ} \mathrm{C}$ for $30 \mathrm{~s}$, primer annealing at $50^{\circ} \mathrm{C}$ for $45 \mathrm{~s}$, and extension at $72^{\circ} \mathrm{C}$ for 60 s. Following the last cycle, the reaction was kept at $72^{\circ} \mathrm{C}$ for 5 min to allow time for completing all the strands.

PCR products were detected by migrating to $1 \%$ agarose gel using a 1xTBE buffer in the Submarine Electrophoresis (Hoefer, USA) device. Observations were carried out with the help of UV light $(\lambda=260 \mathrm{~nm})$ after the gel was colored with Bioatlas (Genaid). DNA markers with a size of $100 \mathrm{bp}$ were used as the indicators of molecular weight.

\section{Sequencing}

The amplified PCR products were purified using the GFX Column purification kit (Amersham, USA), then used as the DNA mold for DNA sequencing reactions. Each sample performed two sequencing reactions using forward and reverse primers. The purification of the reaction sequencing product used G-50 Autoseq column, and the DNA was purified using concentrated absolute alcohol and washed with $70 \%$ alcohol. Afterwards, $6 \mu$ l of stop solution was incorporated, the product was incubated at $72^{\circ} \mathrm{C}$ for 5 minutes and stored in an icebox. The sequencing was carried out to all COX2 gene PCR products. DNA Sequencing used Automatic DNA Sequence AB1 Prism.4.1. A good sequencing result in the Spectrophotogram graphs shows a single peak without any noise.

\section{Data analysis}

Multiple alignments of the nucleotide sequences of the COX2 gene were analyzed using the Clustal W. software. The nucleotide sequence of the COX2 gene was analyzed using MEGA software version 6.06 (Kumar et al. 2018) and the genetic distance was analyzed using the Kimura method with two parameters. Phylogenetic trees were analyzed based on nucleotide sequences with Maximumlikelihood (ML) method with 1000 bootstrap values. As a comparison, Elephas maximus (Access number EF588275.2) were taken from Genbank.

\section{RESULTS AND DISCUSSION}

\section{Variation of the nucleotide of the sequence}

Primer designed to amplify the specific $C O X 2$ gene and the PCR result using the $C O X 2 \mathrm{~F}$ and $C O X 2 \mathrm{R}$ primer is 684 bp that immigrates using 1\% agarose gel (Figure 2). Based on the multiple alignments, the DNA fragment of COX2 is located in tRNA ${ }^{\mathrm{Asp}}$ ( $45^{\text {th }}$ base from $5^{\prime}$ end tRNA ${ }^{\text {Asp }}$ gene) until $684^{\text {th }}$ base inside the $C O X 2$ gene. The total amplified DNA fragment was $684 \mathrm{bp}$, almost similar to the COX2 gene fragment in Tarsius bancanus (Figure 1) reported by Schmitz et al. (2002).

The result of multiple alignments from this research is not deletion and insertion, but rather, producing the same size of the sequence. The sequencing results among the Sumatran elephants (sample) showed no difference between nucleotide and amino acid. However, the comparison with Asian elephants from Genbank shows nine differences of nucleotide with the Asian elephant from India (AJ428946.1) and four differences of nucleotide with Asian elephant from Thailand (EF588275.2); however, no differences in amino acid were observed. Comparing the sample with Mammuthus primigenius and African elephant, there were more than 20 differences of nucleotide that could be attributed to different species and gap of environmental condition of species (see Table. 3 ).

\section{Phylogenetic relationship}

The phylogenetic relationship of Sumatran elephants was examined to fill the gap in the limited sequence data of COX2 gene from Asian elephants in Genbank. The identification of phenogram was analyzed by constructing a phylogenetic tree using the Maximum-likelihood (ML) method.

The phylogenetic tree based on $C O X 2$ nucleotide show that all samples belong to one group. Therefore, the COX2 gene in Sumatran elephant is very stable and limited of mutations. DNA divergence between Elephas maximus sumatranus and other subspecies of Elephas maximus is less than $0.25 \%$. This is supported by Rohland et al. (2010) that the mutation rate of mitochondrial DNA in Asian elephants is only half as much as the mitochondrial DNA in primates, at least in the past 24 million years.

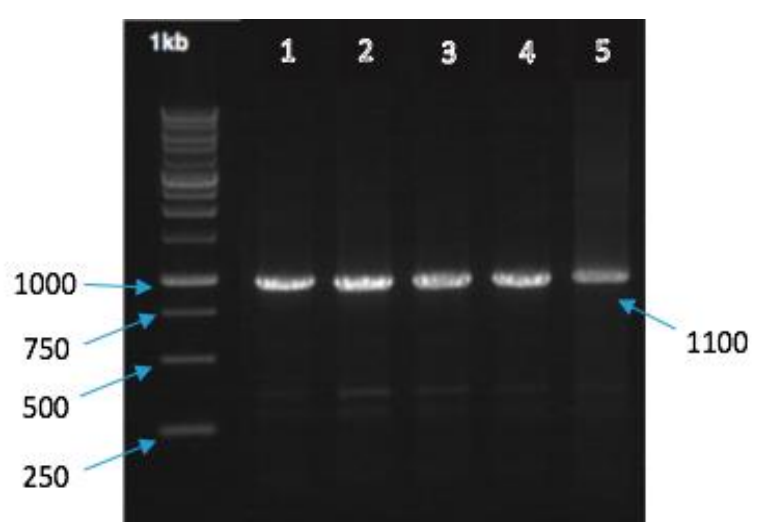

Figures 2. Amplification result of $C O X 2$ gene using primer COX2F and COX2R and $0.8 \%$ agarose gel. Number 1 is DNA ladder $1 \mathrm{~kb}$. Samples number 2-6 are derived from Sumatran elephants. 
Tables 2. List of sample

\begin{tabular}{llll}
\hline Sample & Accession number & Location of sample & Sample origin \\
\hline Elephant_1 & - & Jawa Timur Park & Lampung \\
Elephant_2 & - & Jawa Timur Park & Lampung \\
Elephant_3 & - & Jawa Timur Park & Palembang (South Sumatran) \\
Elephant_4 & - & Jawa Timur Park & Palembang (South Sumatran) \\
Elephant_5 & - & Jawa Timur Park & Palembang (South Sumatran) \\
Elephas maximus & AJ428946.1 & Genbank & India \\
Elephas maximus & EF588275.2 & Genbank & Thailand \\
Mammuthus primigenius & EU153450.1 & Genbank & Siberia \\
Elephas antiquus & KY499558.1 & Genbank & Germany \\
Loxodonta cyclotis & KY616976.1 & Genbank & Africa \\
\hline
\end{tabular}

Tables 3. Nucleotide variations of Sumatran elephant (Elephas maximus sumatranus) based on COX2 genes compared to other Asian elephants, African elephants and mammoth (Genbank data).

\begin{tabular}{|c|c|c|c|c|c|c|c|c|c|c|}
\hline Sample & 1 & 2 & 3 & 4 & 5 & 6 & 7 & 8 & 9 & 10 \\
\hline \multicolumn{11}{|l|}{ Elephant_1 } \\
\hline Elephant_2 & 0 & & & & & & & & & \\
\hline Elephant_3 & 0 & 0 & & & & & & & & \\
\hline Elephant_4 & 0 & 0 & 0 & & & & & & & \\
\hline Elephant_5 & 0 & 0 & 0 & 0 & & & & & & \\
\hline AJ428946.1 Elephas maximus & 9 & 9 & 9 & 9 & 9 & & & & & \\
\hline EF588275.2 Elephas maximus & 4 & 4 & 4 & 4 & 4 & 11 & & & & \\
\hline EU153450.1 Mammuthus primigenius & 26 & 26 & 26 & 26 & 26 & 21 & 26 & & & \\
\hline KY499558.1 Elephas antiquus & 22 & 22 & 22 & 22 & 22 & 21 & 22 & 24 & & \\
\hline KY616976.1 Loxodonta cyclotis & 25 & 25 & 25 & 25 & 25 & 26 & 27 & 27 & 9 & \\
\hline
\end{tabular}

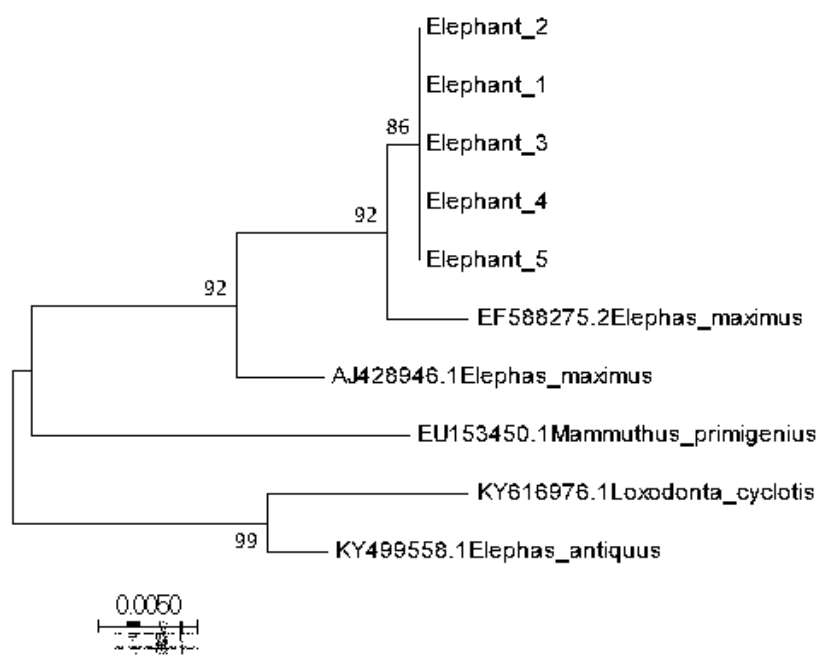

Figures 3. Phylogram of elephant sample research with comparative elephants from Genbank based on COX2 gene nucleotide sequences (684 nt)

\section{Discussion}

The phylogenetic tree of Sumatran elephant based on the COX2 nucleotide shows only a single clade. All samples belong to one clade supported by $86 \%$ of bootstrap. However, Sumatran elephant and Asian elephant from Thailand are favored by $92 \%$ bootstrap (see Figures. 3 ). These results revealed that differences between the species of Sumatran elephants based on COX2 sequence are non-existent.
Table 2 shows a high homogeneity mutation of the COX2 gene in the Mitochondrial DNA of Sumatran elephants. It is due to a low level of isolation of the population, hence low genetic diversity. Additionally, the samples came from the same province (South Sumatra). Brandt et al. (2012) states that it takes at least 100 years of genetic isolation to show the significant genetic variations within a population in one location. It requires a considerably different geographic condition to compare the populations. Nevertheless, this gene is viable to differentiate the subpopulations of the elephants.

Based on the results of genetic analysis using the COX2 gene is very stable, there is showed a low level of nucleotide mutations between sample from Sumatran elephant when compared to the other subspecies of Elephas maximus from Genbank (AJ428946 and EF588275). This study compared 684 sequence nucleotides of COX2 gene with other Asian elephant from GenBank. There is found nine different nucleotides compared to Asian elephant (AJ428946) which is originated from India and four different nucleotides compared to Asian elephant (EF588275) from Thailand. It showed that the mutation between samples and other subspecies of Asian elephants was substitution and synonymous (substitution for nucleotide but equivalent amino acid).

Concerning the phylogenetic amino acid level, the elephants did not show any mutation compared to the Elephas maximus outgroup (Figure 2). Gene in Asian elephants is much conserve than that of African elephants, it showed in African elephants like Loxodonta cyclotis (forest elephants) and Loxodonta Africana (bush elephants) 
that live in the same continental land, their differences in genetic data are sufficient to put them in different species category, not sub-species (Brandt et al. 2012). The difference of these two African elephants can be altogether distinguished morphologically, have different mt-DNA forms two deeply distinctive clades that is designed clade $\mathrm{F}$ and $\mathrm{S}$, and the result from nuclear markers and microsatellites place savanna and forest elephants into monophyletic clades and divergence has been estimated 2.6-5.6 Ma (Brandt et al. 2012; Rohland et al. 2010).

Borneo elephants are an elephant species in Kalimantan Island with distinctive morphology and genetic, which separate them from other Asian elephant subspecies. Borneo elephants are believed to have been isolated in Borneo island for 300.000 years ago, causing genetic lost and significant differences to the subsequent evolution (Goossens et al. 2016). Unlike African elephants, Asian elephants have more homogeneous genetic material, morphology, behavior, and ecology. According to Brandt et al. (2012), the differences were found to African elephants cause the separation of two sub-species $L$. cyclotis and $L$. africana because of geographic condition into different species. Furthermore, Elephas maximus borneensis is morphologically distinct from E. maximus sumatranus, which is a smaller Borneo elephant with tail that touches the ground but remains genetically close to the other $E$. maximus (Goossens et al. 2016).

A study in genetic variation of Sumatran elephants using D-Loop gene from mitochondrial DNA reported a low diversity in Sumatran elephant and a dominant haplotype $(91.4 \%)$ from 105 samples with $0-0.0003$ intrapopulation genetic distance and 0-0.0022 interpopulation genetic distance (Sulandari and Zein 2012). Fleischer et al. (2001) analyzed the Cytochrome $B$ gene from mitochondrial DNA reported two main clades with 2\% genetic distance among Asian elephants from Sri Lanka, India, Nepal, Myanmar, Thailand, Malaysia, and Indonesia. Pierron et al. (2012) reported that neutral mtDNA mutation rate (especially substitutions) is rather varied for short-lived mammals, such as a rodent, but low in long-lived mammals like primates. It may contribute to the low variability of $C O X 2$ gene in Sumatran elephant. Furthermore, tahe low mutation rate in these animals may be an adaptive phenomenon to avoid the accumulation of deleterious mutations in important mt-DNA genes (Pierron et al. 2012).

This study showed that that COX2 gene has a high homogeneity of intraspecies variability and produces new genetic data of Sumatran elephants useful for conservation purposes and further research. Genetic mapping has been widely conducted using mitochondrial DNA or microsatellite to observe the differences among Asian elephant subspecies. Limited data from genetic analysis of Sumatran elephants in Indonesia, especially those in captivity, have prompted the first step in conservation efforts to measure the impact of reduced forests and human interference on wild animal maintenance, especially elephants.
This study concluded that the COX2 gene mitochondrial DNA could not identify individuals in Sumatran elephant due to high level of intraspecies homogeinity in nucleotide sequence. The interspecies divergences using the COX2 gene can tell elephants apart, and this study found that Sumatran elephants are clustered in the clade of Asian elephants. It is suggested that genetic analysis uses more samples from different areas in Sumatran Island to get more comprehensive data.

\section{ACKNOWLEDGEMENTS}

The authors would like to express their gratitude to the Indonesian Ministry of Environment and Forestry; Jawa Timur Park Conservation Institute, Batu, Indonesia; and Department of Biochemistry, Faculty of Veterinary Medicine, Universitas Gadjah Mada (UGM), Yogyakarta, Indonesia. Our warm thanks to drh. Mahcmud Asvan from Gembira Loka Zoo, Yogyakarta, Indonesia for his tremendous assistance and great support, as well as all elephants' keepers. This study was supported by Ministry of Research, Technology and Higher Education of Republic Indonesia through Pendidikan Magister menuju Doktor Sarjana Unggul (PMDSU) Program Batch III with Letter of Appointment Agreement Number 148/SP2H/LT/DRPM/2018 and Number 5704/UN1.DITLIT/DIT-LIT/LT/2018.

\section{REFERENCES}

Alfred R, Ahmad AH, Payne J, William C, Ambu L. 2010. Density and population estimation of the bornean elephants (Elephas maximus borneensis) in Sabah. J Biol Sci 10 (2): 92-102. DOI: 10.3844/ojbsci.2010.92.102.

Azmi W, Gunaryadi D. 2011. Current status of Asian elephants in Indonesia. Gajah 35: 55-61.

Brandt AL, Ishida Y, Georgiadis NJ, Roca AL. 2012. Forest elephant mitochondrial genomes reveal that elephantid diversification in Africa tracked climate transitions. Mol Ecol 21: 1175-1189. DOI: 10.1111/j.1365-294X.2012.05461.x

Chicherin IV, Dashinimaev E, Baleva M, Krasheninnikov I, Levitskii S, Kamenski P. 2019. Cytochrome C oxidase on the crossroads on transcriptional regulation and bioenergetics. Front Physiol 10: 644. DOI: 10.3389/fphys.2019.00644

Fernando P, Pastorini J. 2011. Range-wide status of Asian elephants. Gajah 35: 15-20. DOI: 10.5167/uzh-59036.

Fleischer RE, Perry K, Muralidharan E, Stevens, Wemmer C. 2001. Phylogeography of the Asian elephant (Elephas maximus) based on mitochondrial DNA. Evolution 55: 1882-1892. DOI: 10.1111/j.00143820.2001.tb00837.x.

Galina V, Glazko, Nei M. 2003. Estimation of divergence times for major lineages of primate species. Mol Biol Evol 20 (3): 424-434. DOI: 10.1093/molbev/msg050.

Goossens B, Sharma R, Othman N, Kun-Rodrigues C, Sakong R, Ancrenaz M, Ambu LN, Jue NK, O'Neill RJ, Bruford MW, Chikhi L. 2016. Habitat fragmentation and genetic diversity in natural populations of the Bornean elephant: Implications for conservation. Biol Conserv 196: 80-92. DOI: 10.1016/j.biocon.2016.02.008.

Ishida Y, Nicholas J, Georgiadis, Tamoko H, Alfred LR. 2013. Triangulating the provenance of African elephants mitochondrial DNA. Evol Appl 6: 253-265. DOI: 10.1111/j.17524571.2012.00286.x. 
Islam A, Mohsanin S, Chowdhury GW, Chowdhury SU, Aziz AM, Uddin M, Saif S,Chakma S, Akter R, Jahan I, Azam I. 2011. Current status of Asian elephants in Bangladesh. Gajah 35: 21-24.

Jigme K, Williams AC. 2011. Current status of Asian elephants in Bhutan. Gajah 35: 25-28.

Kumar S, Stecher G, Li M, Knyaz C, Tamura K. 2018. MEGA X Molecular evolutionary genetics analysis across computing platforms. Mol Biol Evol 35 (6): 1547-1549.

Lee EJ, Lee YH, Moon SH, Kim NY, Kim SH, Yang MS, Choi DH, Han MS. 2012. The identification of elephant ivory evidences of illegal trade with mitochondrial Cytochrome B gene and hypervariable Dloop region. J Forensic Leg Med 20: 174-178. DOI: 10.1016/j.jflm.2012.06.014

Ly CT. 2011. Current status of Asian elephants in Vietnam. Gajah 35 104-109.

Maltby M, Bourchier G. 2011. Current status of Asian elephants in Cambodia. Gajah 35: 36-42.

Ministry of Forestry. 2007. Plan and Action Strategy of Sumatran Elephant and Borneo Elephant Conservation 2007-2017. Department of Forestry, Jakarta.

Pierron D, Wildman DE, Huttemann M, Letellier T, Grossman LI. 2012. Evolution of the couple Cytochrome $\mathrm{C}$ and Cytochrome C Oxidase in primates. Adv Exp Med Biol 748: 185-213. DOI: 10.1007/978-14614-3573-0_8.

Pradhan NMB, Williams AC, Dhakal M. 2011. Current status of Asian elephants in Nepal. Gajah 35: 87-92.

Rohland N, Reich D, Mallick S, Meyer M, Green RE, Georgiadis NJ, Roca AL, Hofreiter M. 2010. Genomic DNA sequences from mastodon and woolly mammoth reveal deep speciation of forest and savanna elephants. PLoS Biol 8: e1000564. DOI: 10.1371/journal.pbio.1000564.

Schmitz J, Ohme M, Zischler H. 2002. The complete mitochondrial sequence of Tarsius bancanus: Evidence for an extensive nucleotide compositional plasticity of primate mitochondrial DNA. Mol Biol Evol 19: 544-553. DOI: 10.1093/oxfordjournals.molbev.a004110

Sulandari S, Zein MSA. 2012. Mitochondrial DNA variation of the sumatran elephant populations in Sumatera Indonesia. Biotropia 19 (2): 92-102.

Widayanti R, Handayani NSH, Budiarsa IM. 2010. The Molecular study on mitochondrial Cytochrome Oxidase 2 (COX2) gene of Tarsius sp. Biota J 15 (1): 98-106.

Zhang L. 2011. Current status of Asian elephants in China. Gajah 35: 43 46. 